\begin{tabular}{|l|l|}
\hline $\begin{array}{l}\text { Instituto de } \\
\text { Geriatria e Gerontologia }\end{array}$ & $\begin{array}{l}\text { Pan American Journal of Aging Research } \\
\text { PAJAR, Porto Alegre, v. 8, p. 1-10, jan.-dez. } 2020 \\
\text { ISSN-L: 2357-9641 }\end{array}$ \\
\hline http://dx.doi.org/10.15448/2357-9641.2020.1.35893 & \\
\cline { 1 - 2 }
\end{tabular}

ARTIGO ORIGINAL

\title{
Family Functionality, cognitive status and social participation are related to survival in nonagenarians and centenarians: data from a Brazilian cohort study
}

\author{
Funcionalidade familiar, condição cognitiva e participação social estão relacionados com \\ a sobrevida em nonagenários e centenários: dados de um estudo de coorte brasileiro. \\ Funcionalidad familiar, condición cognitiva y participación social relacionadas com la \\ supervivencia em nonagenarios y centenarios: datos de un estudio de cohorte brasileño
}

\author{
Ilva Inês Rigo' ${ }^{1}$ \\ orcid.org/0000-0003-3073-5844 \\ ilvainesrigo@gmail.com
}

\section{Ângelo José Gonçalves \\ Bós ${ }^{1}$ \\ orcid.org/0000-0003-4901-3155 angelo.bos@pucrs.br}

Recebido em: 3 out. 2019. Aprovado em: 17 dez. 2019. Publicado em: 03 agos. 2020.

\section{(c) (i)}

Artigo está licenciado sob forma de uma licença Creative Commons Atribuição 4.0 Internacional.

\section{Abstract}

Aim: To evaluate whether family functionality, using the instrument "Adaptation, Partnership, Growth, Affection, and Resolve" (APGAR) and its components, as well as other health indicators, influences the survival of nonagenarians and centenarians. Methods: Participants were randomly identified and evaluated in their homes of Porto Alegre - Brazil. Death or survival information were verified by telephone or death registry system. Follow-up time measured the number of months between the first evaluation and the date of death or the last contact. Participants with APGAR $\geq 7$ were classified with good functionality. The APGAR components were analyzed as yes or no. Results: Two-hundred-fourteen participants (73\% women, age $92.4 \pm 3.59$ years) were followed during $23 \pm 10.0$ months. Sixty-on (28.5\%) died. Survivors were younger $(p<0.001)$, had better cognitive performance $(p<0.001)$, and reported more frequently leaving home ( $p=0.010)$ and participating in social activities $(p<0.001)$. Survivors had a similar frequency for good family functioning ( $90 \% p=0.994$ ), but more often they were satisfied with their family time $(p=0.032)$ and with the way the family showed affection and reacted to their feelings $(p=0.083)$.

Conclusions: Family affection and time were significantly associated with lower hazard-ratio, even adjusted for age, as well as cognitive performance, social activities and the habit of leaving home. In addition to the preservation of cognitive performance, to remain physically and socially active, family support is related to the higher survival rate in nonagenarians and centenarians in Brazil.

Keywords: Family relations; Aged, 80 and over; Survival analysis.

\section{Resumo}

Objetivo: Avaliar se a funcionalidade familiar, utilizando o instrumento APGAR da familia e seus componentes, assim como outros indicadores de saúde, influenciam a sobrevida de nonagenários e centenários.

Métodos: Os participantes foram identificados e avaliados aleatoriamente em suas residências em Porto Alegre - Brasil. As informações sobre óbito ou sobrevivência foram verificadas por telefone ou sistema de registro de óbitos. O tempo de acompanhamento mediu o número de meses entre a primeira avaliação e a data da morte ou o último contato. Os participantes com APGAR $\geq 7$ foram classificados com boa funcionalidade. Os componentes do APGAR foram analisados como sim ou não. Resultados: Duzentos e quatorze participantes (73\% mulheres, idade 92,4 \pm 3.59 anos) foram acompanhados durante $23 \pm 10,0$ meses. Sessenta e oito $(28,5 \%)$ morreram. Os sobreviventes eram mais jovens ( $p<0,001)$, apresentaram melhor desempenho cognitivo $(p<0,001)$ e relataram mais frequentemente sair de casa ( $p$ $=0,010$ ) e participar de atividades sociais $(p<0,001)$. Os sobreviventes tiveram uma frequência semelhante para o bom funcionamento da familia $(90 \% p=0,994)$, mas maior frequência de satisfação com o tempo que passavam com familia $(p=0,032)$ e com a maneira como a família mostrou afeto e reagiu aos sentimentos $(p=0,083)$. 
Conclusões: $O$ afeto e o tempo com a família associaram-se significativamente a menor chance de óbito, mesmo ajustada pela idade, bem como desempenho cognitivo, atividades sociais e hábito de sair de casa. Além da preservação do desempenho cognitivo, manter-se física e socialmente ativo, o apoio familiar está relacionado à maior taxa de sobrevida em nonagenários e centenários no Brasil. Palavras-chave: Relações familiares; idoso de 80 anos ou mais; análise de sobrevida.

\section{Resumen}

Objetivo: evaluar si la funcionalidad familiar que utiliza el instrumento APGAR familiar y sus componentes, asi como otros indicadores de salud, influyen en la supervivencia de los nonagenarios y centenarios.

Métodos: los participantes fueron identificados al azary evaluados en sus residencias en Porto Alegre - Brasil. La información sobre muerte o supervivencia se verificó por teléfono o mediante un sistema de registro de defunciones. El tiempo de seguimiento midió el número de meses entre la primera evaluación y la fecha de la muerte o el último contacto. Los participantes con APGAR $>6$ fueron calificados con buena funcionalidad. Los componentes APGAR se analizaron como sí o no. Resultados: Doscientos catorce participantes (73\% mujeres, edad $92.4 \pm 3.59$ años) fueron seguidos durante $23 \pm 10.0$ meses. Sesenta y ocho $(28.5 \%)$ murieron. Los sobrevivientes eran más jóvenes ( $p<0.001$ ), tenian un mejor rendimiento cognitivo $(p<0.001)$ y reportaron más a menudo salir de casa $(p=0.010)$ y participar en actividades sociales $(p<0.001)$. Los sobrevivientes tuvieron una frecuencia similar para el funcionamiento familiar $(90 \% \mathrm{p}=0,994)$, pero una mayor frecuencia de satisfacción con el tiempo que pasaron con la familia $(p=0,032)$ y la forma en que la familia mostró afecto y reaccionó a los sentimientos. $(p=0,083)$.

Conclusiones: el afecto y el tiempo con la familia se asociaron significativamente con una menor probabilidad de muerte, incluso ajustada por edad, así como con el rendimiento cognitivo, las actividades sociales y el hábito de salir de casa. Además de preservar el rendimiento cognitivo, mantenerse activo fisica y socialmente, el apoyo familiar está relacionado con la mayor tasa de supervivencia de los no nonagenarios y centenarios en Brasil.

Palabras clave: Relaciones familiares; anciano de 80 años o más; análisis de supervivencia.

\section{Introduction}

Demographic aging is a fast-growing problem in developing countries, like Brazil. It results from the reduction of birth and fertility rates and the increase in life expectancy, due to the decrease in mortality. This decrease is due, among other causes, to greater access to health services. Among the older-adults, the population range of those aged 80 years or older, also called oldest-old, is the one that grows the most ${ }^{1}$.It is estimated that in 2050, the oldest-old will be 13.3 million people, representing $6.5 \%$ of the Brazilian population and $19.6 \%$ of the elderly ${ }^{2}$. Paschoal (2016) recalls that aging is accompanied by a greater chance of illness and decline of autonomy and independence 3 .

The family is the natural space of care for the individuals ${ }^{4}$. The weight of the aging process for families, especially from developing countries, is heavy. In developing countries, like Brazil, family and other informal social institutions assume the care role with little or no state support. As early as 1996 , Rogers ${ }^{5}$ noted that family composition and social support are related to mortality. Few current studies attempt to demonstrate this relationship in oldest-old in developing countries.

Even though the oldest-old is the fastest growing population stratum that needs the most care, there are still few studies in Brazil and in the world that address this stratum of the population. One of the research groups that carries out the monitoring of oldest-old is the Multiprofessional Care for the Oldest-Old (AMPAL) Project. This group identified that, in Brazil, oldest-old people faces difficulties in access to health care, showing a significant frequency of mortality due to undefined causes and death without medical care 1. Since 2016, AMPAL has carried out the home monitoring of people aged 90 years or older in several neighborhoods of Porto Alegre.

Although the family is the primary center of care, just living with someone does not imply being well cared for ${ }^{6}$. The good family functionality, measured through family APGAR (Adaptation, Partnership, Growth, Affection, and Resolve) tool, evaluating the support perceived by the oldest-old in front of their needs could be a factor related to the greater oldest-old survival. To date, this issue has not been explored in the international literature much less in the national literature, and this is the focus of the present study. Thus we aimed to study the relationship between family functionality, sociodemographic profile, health, cognitive status, interaction and social support with the survival of nonagenarians and centenarians.

\section{Methods}

Longitudinal, observational and analytical study. The data collected by the AMPAL project were used in the initial evaluation performed in 2016. Surveillance for survival data was performed by telephone contact. 
The present research has as population nonagenarians and centenarians resident in private households living in Porto Alegre - Brazil who participated in the Multiprofessional Care to $\mathrm{Ol}$ dest-old (AMPAL) project will be used as sample. All the AMPAL project's oldest-old respondents were included in the present study, who answered the Family APGAR questionnaire in the initial evaluation of 2016. Excluded are those whose only available information or contact was in the initial evaluation of 2016. These participants were considered losses and without follow-up time.

Data from the initial AMPAL assessment were collected at the household of the oldest-old, with their own or their relatives.

The deaths of the participants were identified through the reports of the Funeral Service Center of Porto Alegre (CAF) and through telephone contact. From August 2018 to January 2019 all participants whose survival situation could not be observed in the CAF report were contacted by telephone for a follow-up interview.

The family functionality was evaluated through the family APGAR, developed by Smilkstein (1978) 7 and validated in Brazil by Duarte (2001) ${ }^{8}$. In the present study, two levels of family functionality will be considered: good functionality (APGAR 7 to 10) and family dysfunction (o to 6). In cases in which the participant was not able to respond, the APGAR of the family was not filled out, and excluded from this study. In order to avoid embarrassment, while the participant answered the APGAR questions, family members were asked separately about other issues, such as medication in use and chronic diseases.

Regarding sociodemographic data, this study evaluated schooling and marital state. Social interaction was described by the average number of days per month that left home in the last six months, frequency that receives visits per week, frequency that participates in social activities per week. The self-perception of health was answered by the oldest-old itself, by means of simple choice of the questions: optimal, good, regular, bad, poor or could not respond, if the oldest-old were not able to do so, the latter were not used for analysis. The measurement of the cognitive condition was made in the first AMPAL interview through the MMSE (Mini-Mental
State Examination). The cutoff point for screening for cognitive impairment was used as recommended by Lourenço \& Veras (2006)9: 18 for illiterates and 24 for those with school education. Screening for geriatric depression was performed with the GDS-5 (Five Items Geriatric Depression Scale), validated by Almeida (2010) ${ }^{10}$, in which suspicion of depression occurs if there is a score equal to or greater than 2.

The descriptive analysis compared the distribution of sociodemographic and clinical factors and family functionality between the study situation levels (survivors and deaths). Each of the components of family functionality was categorized dichotomically into yes (sometimes or always) and not (never). The association between these variables and the situation in the study were tested by Chi-Square, or Fischer's exact test if the expected number of observations at the intersection was less than 5. Mean age, number of depressive symptoms and cognitive assessment performance (MMSE) were calculated for survivors and deaths and tested by Student's T. The analysis was performed using the Epilnfo version 7. The tests with $\mathrm{p}<0.05$ (5\%) and very significant when $<0.01$ (1\%) and indicative of significance when between 0.1 and 0,05 .

Survival analysis was performed using the Kaplan Meier curves, in which differences in the survival of groups with good family functionality or with family dysfunction observed at baseline could be observed (initial evaluation). Through the Cox Damage regression, the Hazard Ratio was obtained, with which it was observed whether significant differences in the descriptive analysis between the groups with good family functionality or with family dysfunction observed in the initial AMPAL evaluation influenced the survival in both groups.

The AMPAL Project (umbrella) was approved by the Research Ethics Committee of Pontifical Catholic University of Rio Grande do Sul (PUCRS). All the participants signed a Term of Free and Informed Consent authorizing the research and telephone contact. This research project was submitted and approved by the IGG Scientific Committee and the Research Ethics Committee PUCRS. The researchers commit to the confidentiality of the use of data from the AMPAL project and the CAF report through the Data Use Commitment Term. 


\section{Results}

Among AMPAL participants, 228 had the family APGAR filled. With fourteen participants it was not possible to perform contact after the first evaluation, i.e., they did not have follow-up. These participants could not be included in the survival analysis, leaving 214 participants. The participants had their first evaluation as of June 2016 and the last contact attempt in March 2019, a maximum of 33 months of follow-up.

Table 1 shows the sociodemographic data, follow-up time and cognitive conditions of the participants with follow-up according to the situation (survivor or death) until the last connection. The mean follow-up time was $23.22 \pm 10.02$ months. During follow-up, 61 deaths were identified. In the analysis by situation in the study, there was no significant difference between the sexes. There was a very significant difference in the mean age between the surviving participants and those who died ( $p<0.001$ ), the latter being older. By stratifying participants by age group, up to 91 years and 92 years and over, the highest frequency of deaths among the oldest (63.93\%) was confirmed, a very significant relation $(p=0.001)$. The follow-up time was significantly higher among alive participants, who had about 12 months of follow-up ( $p<0.001$ ). Among the deaths, the MMSE performance was worse $(p<0.001)$ and the occurrence of altered MMSE was more frequent $(p<0.001)$. Regarding the self-reported color, white represented $83.18 \%$, among which there was a higher frequency of survivors $(p=0.765)$. The other categories were aggregated into one, non-white. Participants in the surviving group had a higher number of depressive symptoms $(p=0.785)$ and a higher frequency of depression $(p=0.841)$. Survivors had a lower frequency of poor or poor self-perception $(p=0.317)$.

TABLE 1 - Socio-demographic data, follow-up time, and cognitive and clinical conditions of the AMPAL Participants, according to the situation $(n=214)$.

\begin{tabular}{|c|c|c|c|c|}
\hline & Survivor & Deceased & Total & p \\
\hline Follow-up months (mean \pm SD) & $26.75 \pm 8.32$ & $14.37 \pm 8.34$ & $23.22 \pm 10.02$ & $<0.001$ \\
\hline $\operatorname{Sex}(n(\%))$ & & & & 0.797 \\
\hline Female & $113(73.86)$ & $44(72.13)$ & 157(73.36) & \\
\hline Male & $40(26.14)$ & $17(27.87)$ & $57(26.64)$ & \\
\hline Age $($ mean $\pm S D)$ & $91.82 \pm 3.25$ & $93.79 \pm 4.03$ & $92.38 \pm 3.59$ & $<0.001$ \\
\hline Age group & & & & 0.001 \\
\hline$<92$ years & $92(60.13)$ & $22(36.07)$ & $114(53.27)$ & \\
\hline$\geq 92$ years & $61(39.87)$ & $39(63.93)$ & $100(46.73)$ & \\
\hline Marital status (n (\%)) & & & & 0.314 \\
\hline Married & $32(20.92)$ & 11(18.03) & $43(20.9)$ & \\
\hline Divorced & 6(3.92) & $O(0)$ & 6(3.92) & \\
\hline Not married & $13(8.5)$ & $8(13.11)$ & $21(9.81)$ & \\
\hline Widower & 102(66.67) & $42(68.85)$ & $144(67.29)$ & \\
\hline Color (n (\%)) & & & & 0.765 \\
\hline White & $128(83.66)$ & $50(81.97)$ & $178(83.18)$ & \\
\hline Other & $25(16.34)$ & 11(18.03) & $36(16.82)$ & \\
\hline Years of study (mean \pm SD) & $6.32 \pm 4.51$ & $6.02 \pm 4.61$ & $6.23 \pm 4.53$ & 0.659 \\
\hline MMSE (points \pm SD) & $22.66 \pm 5.48$ & $16.98 \pm 6.48$ & $21.04 \pm 6.31$ & $<0.001$ \\
\hline Normal MMS & $122(79.74)$ & $17(27.87)$ & $139(64.95)$ & $<0.001$ \\
\hline MMSE changed & $31(20.26)$ & $44(72.13)$ & $75(35.05)$ & \\
\hline GDS (points \pm SD) & $1.49 \pm 1.08$ & $1.44 \pm 1.31$ & $1.48 \pm 1.15$ & 0.785 \\
\hline
\end{tabular}




\begin{tabular}{|c|c|c|c|c|}
\hline & Survivor & Deceased & Total & p \\
\hline Suspicion of Depression & & & & 0.841 \\
\hline Yes (GDS $\geq 2$ ) & $65(42.48)$ & $25(40.98)$ & $90(42.06)$ & \\
\hline No (GDS <2) & $88(57.52)$ & $36(59.02)$ & $124(57.94)$ & \\
\hline Self-perceived health (n (\%)) & & & & 0.317 \\
\hline Very Good or good & $91(59.48)$ & $40(65.57)$ & $131(61.21)$ & \\
\hline Regular & $50(32.68)$ & 14(22.95) & $64(29.91)$ & \\
\hline Bad or Very bad & $12(7.84)$ & $7(11.48)$ & $19(8.88)$ & \\
\hline Total & $153(71.50)$ & $61(28.50)$ & $214(100)$ & \\
\hline
\end{tabular}

Table elaborated by the authors (2019).

Table 2 shows the distribution of social interaction characteristics and family functionality among AMPAL participants according to the situation in the study. Surviving participants reported leaving home more frequently $(0=0.01)$, participating more in social activities $(p<0.001)$, and receiving more visits $(p=0.419)$. The occurrence of familial dysfunction was quite similar between the de- ath and survivor groups $(p=0.994)$. The survivor group reported better satisfaction in each of the components of family functionality, with the relationship of significance $(p=0.083)$ to satisfaction with the way in which their family demonstrates affection and reacts to their feelings and significant ( $p=0.032$ ) to the satisfaction with the time that passes with his family.

TABLE 2 - Social interaction and family functionality among AMPAL participants according to the situation in the study $(n=214)$.

\begin{tabular}{|c|c|c|c|c|}
\hline & Survivor & Deceased & Total & $\mathrm{p}$ \\
\hline Leave home (n (\%)) & 133(86.93) & $44(72.13)$ & $177(82.71)$ & 0.010 \\
\hline Homebounded & $20(13.07)$ & $17(27.87)$ & $37(17.29)$ & \\
\hline Receive visits (n (\%)) & & & & 0.419 \\
\hline Yes & $123(80.39)$ & $46(75.41)$ & $169(78.97)$ & \\
\hline Not & $30(19.61)$ & $15(24.59)$ & $45(21.03)$ & \\
\hline Participates in social activities (n (\%)) & & & & $<0.001$ \\
\hline Yes & $39(25.49)$ & 3(4.92) & 42(19.63) & \\
\hline Not & $114(74.51)$ & $58(95.08)$ & $172(80.37)$ & \\
\hline Family dysfunction (n (\%)) & & & & 0.994 \\
\hline Yes & $15(9.80)$ & $6(9.84)$ & $21(9.81)$ & \\
\hline Not & $138(90.20)$ & $55(90.16)$ & 193(90.19) & \\
\hline \multicolumn{5}{|l|}{ Components of the APGAR of the Family } \\
\hline \multicolumn{4}{|c|}{ Are you satisfied with the help you receive from the family? } & 0.211 \\
\hline Not & $4(2.61)$ & $3(4.92)$ & $7(3.27)$ & \\
\hline Yes & 149(97.39) & $58(95.08)$ & 207(96.73) & \\
\hline \multicolumn{4}{|c|}{ Are you satisfied with the way your family and you talk and share the problems? } & 0.479 \\
\hline Not & $5(3.27)$ & $2(3.28)$ & $7(3.27)$ & \\
\hline Yes & 148(96.73) & 59(96.72) & 207(96.73) & \\
\hline
\end{tabular}




\begin{tabular}{|c|c|c|c|c|}
\hline & Survivor & Deceased & Total & $\mathbf{p}$ \\
\hline \multicolumn{4}{|c|}{$\begin{array}{l}\text { Are you satisfied with the way your family accepts and supports your desire to start, change or } \\
\text { maintain activities or lifestyle? }\end{array}$} & 0.211 \\
\hline Not & $4(2.61)$ & 3(4.92) & 7(3.27) & \\
\hline Yes & 149(97.39) & $58(95.08)$ & 207(96.73) & \\
\hline \multicolumn{4}{|c|}{$\begin{array}{l}\text { Are you satisfied with the way your family demonstrates affection and responds to your feelings } \\
\text { such as irritation, hurt or love? }\end{array}$} & 0.083 \\
\hline Not & $2(1.31)$ & $3(4.92)$ & $5(2.34)$ & \\
\hline Yes & 151(98.69) & $58(95.08)$ & 209(97.66) & \\
\hline \multicolumn{4}{|c|}{ Are you satisfied with the time you spend with your family? } & 0.032 \\
\hline Not & 2(1.31) & $4(6.56)$ & $6(2.80)$ & \\
\hline Yes & 151(98.69) & $57(93.44)$ & 208(97.20) & \\
\hline Total & $153(71.50)$ & $61(28.50)$ & $214(100)$ & \\
\hline
\end{tabular}

Table elaborated by the authors (2019).

The Kaplan-Meier curves for the probability of survival at the sociodemographic and clinical variables levels are shown in figure 1 . Figure $1 \mathrm{~A}$ compares the survival curves of men and women.
It is possible to observe that the male survival, in general, is greater than the female survival, although not significant $(p=0.827)$.

Figure 1 - Kaplan Meier survival probability curve according to socio-demographic and clinical characteristics.
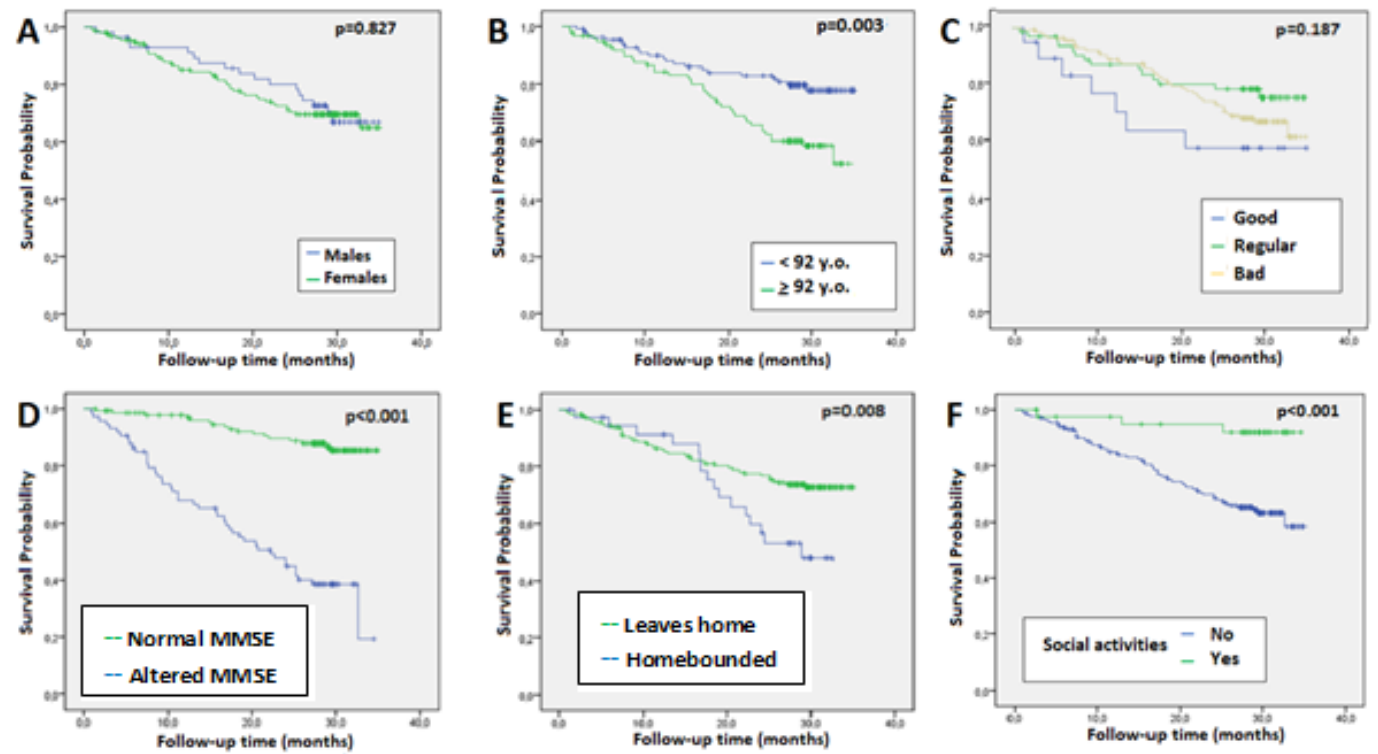

Figure $1 \mathrm{~B}$ shows that the survival curve of the nonagenarians younger than 92 years presents a larger area, representing a greater survival $(p=$ 0.003 ). Figure $1 \mathrm{C}$ shows lower survival among participants who considered their health as bad or bad, when compared to those who reported regular, good or optimal health, although not significant $(p=0.187)$. Regarding the performance in the MMSE, the participants were classified according to the test score and schooling. It can be seen in Figure 1D that the participants with normal MMSE had greater survival than those 
with a score below the limit $(p<0.001)$. Figure $1 E$ shows the participants' Kaplan-Meier curve in relation to leaving or not at home. Longer survival was observed among participants leaving home $(p=0.008)$. Participating in social activities (Figure $1 F)$ was a factor related to higher survival among AMPAL nonagenarians ( $p=0.001$ ).

Figure 2 demonstrates the survival of AMPAL participants according to the score given in each Family APGAR question. The variables satisfaction with family support, problem sharing and family support to the wishes of the nonagenarian demonstrate worse survival among those who were not satisfied with these questions, although without significant difference $(p=0.311,0.441$ and 0.215 , respectively). However, the variables satisfaction with the affection demonstration and with the time spent with the family had a significant difference, with a worse survival among those who answered not being satisfied with these questions ( $p=0.034$ and 0.043 , respectively). Regarding family dysfunction (Figure F), there appears to be longer survival of those who did not present any dysfunction, although not significant ( $p=0.665$ ).

Figure 2 - Kaplan Meier Survival curves of AMPAL nonagenarians according to the components of family functioning.
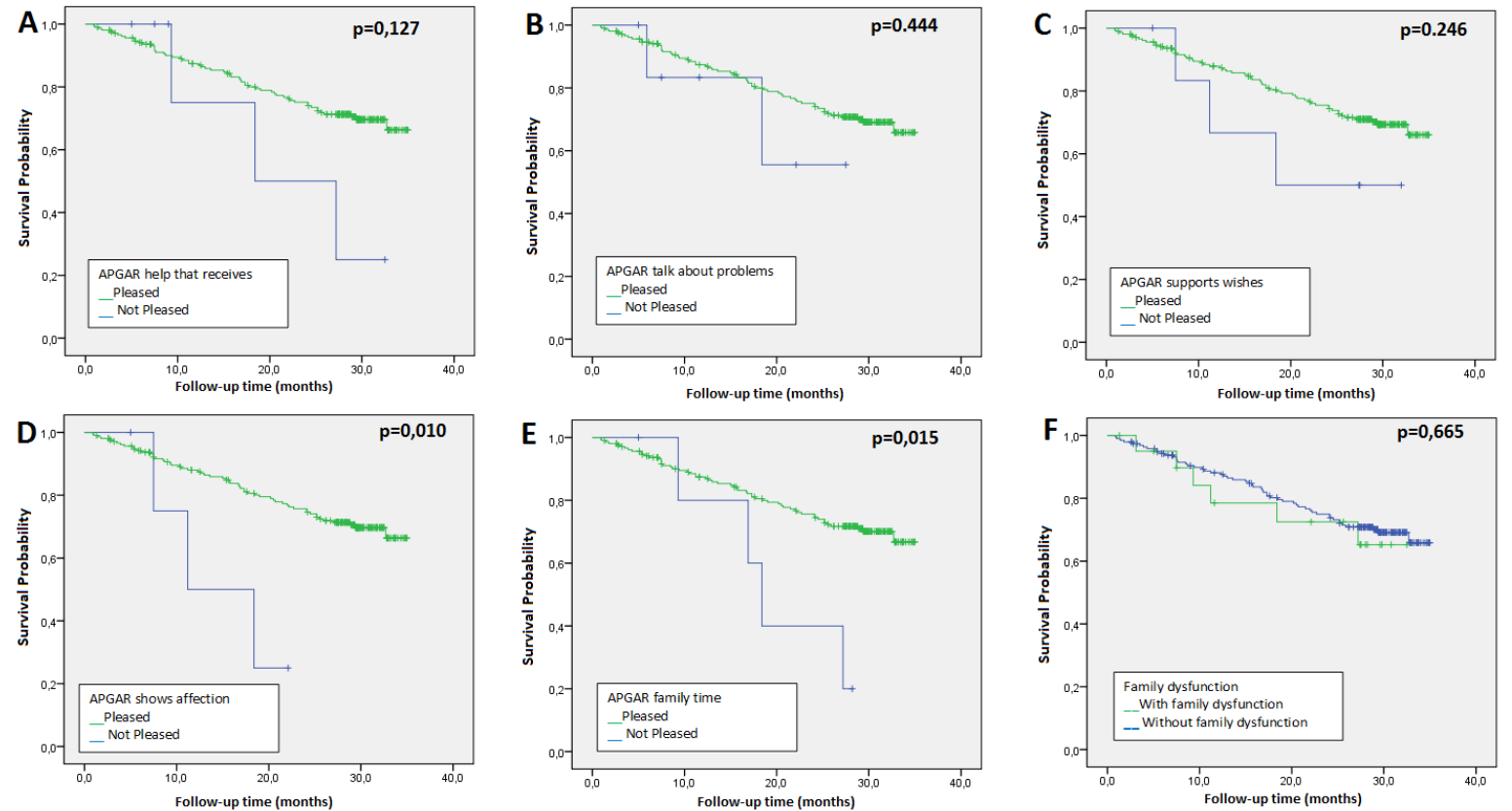

A "Are you satisfied with the help you receive from the family?"; B. "Are you satisfied with the way your family and you talk and share the problems?"; W. "Are you satisfied with the way your family accepts and supports your desire to start, change or maintain activities or lifestyle?"; D. "Are you satisfied with the way your family shows affection and responds to your feelings such as irritation, hurt or love?"; 2E. "Are you satisfied with the time you spend with your family?"; F. with and without Family Dysfunction.

Table 3 shows the results of the Cox Damage regression for the variables that had a significant difference in the survival analysis. Initially, a simple analysis was performed, which was adjusted by the age group, smaller or larger and equal to 92 years. Sex was included in the analysis because it was a factor associated with survival. Family dysfunction was included as the variable of in- terest in this study. Sex and family dysfunction remained without significant difference, even after adjusting for age group $(p=0.724$ and 0.568 , respectively). The age group greater than or equal to 92 years represented a 118\% higher risk of death among nonagenarians and centenarians of AMPAL $(p=0.004)$. 
TABLE 3 - Results of Cox Damage Regression simple and adjusted by the 92-year age group of AMPAL participants $(n=214)$.

\begin{tabular}{|c|c|c|c|c|}
\hline & \multicolumn{2}{|c|}{ Simple analysis } & \multicolumn{2}{|c|}{$\begin{array}{l}\text { Analysis adjusted for age } \\
\text { group }\end{array}$} \\
\hline & HR (IC95\%) & $\mathrm{p}$ & HR (IC95\%) & p \\
\hline \multicolumn{5}{|l|}{ Sex (Female Ref.) } \\
\hline Male & $0.94(0.54-1.65)$ & 0.827 & $1.11(0.63-1.96)$ & 0.724 \\
\hline \multicolumn{5}{|l|}{ Age group (Ref. <92) } \\
\hline$\geq 92$ & $2.18(1.29-3.67)$ & 0.004 & - & - \\
\hline MEEM & $0.89(0.86-0.93)$ & $<0.001$ & $0.90(0.87-0.93)$ & $<0.001$ \\
\hline MMSE (normal) * & $0.14(0.08-0.26)$ & $<0.001$ & $0.16(0.09-0.28)$ & $<0.001$ \\
\hline Participate in social activities * & $0.19(0.06-0.59)$ & 0.005 & $0.20(0.06-0.65)$ & 0.007 \\
\hline Leave home* & $0.48(0.27-0.84)$ & 0.01 & $0.54(0.31-0.96)$ & 0.035 \\
\hline Family dysfunction * & $1.21(0.52-2.80)$ & 0.665 & $1.28(0.55-2.98)$ & 0.568 \\
\hline $\begin{array}{l}\text { Are you satisfied with the help you receive } \\
\text { from the family? * }\end{array}$ & $0.42(0.13-1.33)$ & 0.140 & $0.42(0.13-1.35)$ & 0.145 \\
\hline $\begin{array}{l}\text { Are you satisfied with the way your family } \\
\text { and you talk and share the problems? }\end{array}$ & $0.58(0.14-2.39)$ & 0.450 & $0.48(0.12-1.99)$ & 0.313 \\
\hline $\begin{array}{l}\text { Are you satisfied with the way your family } \\
\text { accepts and supports your desire to start, } \\
\text { change or maintain activities or lifestyle? }\end{array}$ & $0.51(0.16-1.63)$ & 0.254 & $0.53(0.17-1.70)$ & 0.287 \\
\hline $\begin{array}{l}\text { Are you satisfied with the way your family } \\
\text { demonstrates affection and responds to } \\
\text { your feelings such as irritation, hurt or love? }\end{array}$ & $0.24(0.08-0.79)$ & 0.018 & $0.27(0.08-0.86)$ & 0.027 \\
\hline $\begin{array}{l}\text { Are you satisfied with the time you spend } \\
\text { with your family? }\end{array}$ & $0.30(0.11-0.84)$ & 0.022 & $0.27(0.10-0.76)$ & 0.013 \\
\hline
\end{tabular}

Table ellaborated by the authors (2019). "ref: no

The cognitive condition was important for the survival of AMPAL participants. Each plus point in the MMSE represented a 10\% less chance of dying. Having a normal MMSE for schooling represented $84 \%$ less chance of dying. These associations remained significant even after adjustment by age group. Participating in social activities and leaving home meant, respectively, 80 and $46 \%$ less chance of dying, even after adjustment by age group.

\section{Discussion}

Sociodemographic characteristics of AMPAL's nonagenarians and centenarians were like other studies, regarding the mean age, sex composition and marital status ${ }^{11}$. The schooling of AMPAL participants was superior to international studies in Portugal ${ }^{12}$ and China ${ }^{13}$.

In the present study, the good family functionality was presented by most of the nonagenarians and centenarians interviewed, like what happened in the study by Vera et al. (2015) ${ }^{11}$ with people aged 80 or over in the community. The APGAR level of AMPAL participants was better than in a Chinese study ${ }^{14}$, where family disfunction (FD) (52.2\%) prevailed.

The age was significant in the survival analysis, in the Kaplan Meier curves and in the Cox Regression. Being age greater than or equal to 92 years represented a high risk of death among AMPAL 
participants. The older age was also related to a higher risk of mortality in the study by Samper-Ternent et al. (2012)15. In fact, age is considered one of the main factors related to mortality, since as time passes, they can also increase cognitive and functional impairments.

The familiar functionality, variable of interest in the present study, was not significantly associated with the survival of the AMPAL participants, although participants dissatisfied with the family relationships presented lower survival. No survival studies were found that addressed family functionality in the national and international literature. The components of the APGAR regarding satisfaction with the time spent with the family were indicative of significance in the descriptive analysis between the surviving and the deceased groups. This result may reflect what is happening in the families, each member taking care of their own tasks and using their free time in web activities instead of interacting with the other family members, like nonagenarians and centenarians. In addition, many of the family friends of the same age passed away, restricting the possibilities of interaction. In the present study, the quality of family relationships seems to be as important as material and functional support. These issues were addressed by a qualitative study conducted in Finland, in which nonagenarians reported on the importance of living with family, friends and neighbors. In that study, some participants stated that distance would not be a problem because they had access and knew how to use the current media to keep in touch with their family and friends ${ }^{16}$. Training the nonagenarian and centenarian skills and developing assistive technologies that favor such contact can be alternatives to re-approach the oldest-old of your family and friends. On the other hand, during interviews, it was noticed that almost all participants had a well-established family support network. In this context, few participants demonstrate family dysfunction, making it difficult to compare the groups, especially those with family dysfunction. We believe that a larger sample can confirm that nonagenarians and centenarians with worse fa- mily functionality have lower survival rates.

The main factors related to survival in the present study were cognition, social interaction and physical functionality. The mean MMSE performance differed significantly between the surviving and the deceased group, the better MMSE performance represented a longer survival and a $84 \%$ lower risk of death compared to nonagenarians with abnormal MMSE. This finding was similar to that reported by a study with elderly individuals aged 80 years or older in China, among whom there was a higher mortality in the group that presented faster cognitive decline ${ }^{17}$.

Social interaction, evaluated in the form of leaving or not at home and participating in social activities such as groups, meetings with friends, had a significant association with greater survival and was a protective factor for mortality. This association remained significant after adjustment for age group. A meta-analysis with several age groups, but with a predominance of the elderly, identified social isolation and solitude as risk factors for mortality ${ }^{18}$. Among the nonagenarians, social interaction becomes more difficult, due to the physical dependence that some present, and by the network of friendships and family that is waning with the death of many loved ones.

\section{Conclusion}

This study concludes that active aging plays a fundamental role in the maintenance of the quality of life for the elderly. Reaching this age is already a great achievement, but mastery of your own body and intellect goes beyond the simple absence of disease. The predominance of satisfaction with family relationships demonstrates the role of the family as a support structure for nonagenarians and centenarians, without which, possibly, these individuals would not have reached longevity. It is necessary to cultivate and devote time to these relationships in order to keep them active. Having someone to share life with can be one of the reasons to stay alive. 


\section{Acknowledgements:}

This study was financed in part by the Coordenação de Aperfeiçoamento de Pessoal de Nivel Superior - Brazil (CAPES) - Finance Code 001.

\section{References}

1. Camacho NCA, Morche KR, Muller ALW, Bós AJG Por que nonagenários não se tornam centenários no Brasil? Rev AMRIGS. 2018;62(1):55-59.

2. Camarano AA, Kanso S. Envelhecimento da população brasileira: uma contribuição demográfica. In: Freitas EV, Py L, editors. Tratado de geriatria e gerontologia. Rio de Janeiro: Guanabara Koogan; 2016. p. 141-164

3. Paschoal SMP. Qualidade de vida na velhice. In: Freitas EV, Py L, editors. Tratado de geriatria e gerontologia. Rio de Janeiro: Guanabara Koogan; 2016. p. 184-194.

4. Lemos ND, Medeiros SL. Suporte social ao idoso dependente. In: Freitas EV, Py L, editors. Tratado de geriatria e gerontologia. Rio de Janeiro: Guanabara Koogan; 2016. p. 2211-2218.

5. Rogers RG. The Effects of Family Composition, Health, and Social Support Linkages on Mortality. J Health Soc Behav. 1996;37(4):326-338. https://doi. org/10.2307/2137260.

6. Debert GG, Simões JA. Envelhecimento e velhice na familia contemporânea. In: Freitas EV, Py L, editors. Tratado de Geriatria e Gerontologia. 3. ed. Rio de Janeiro: Guanabara Koogan; 2011. p. 1571-1579.

9. Lourenço RA, Veras RP. Mini-Exame do Estado Mental: caracteristicas psicométricas em idosos ambulatoriais. Rev Saúde Pública. 2006;40(4):712-719. https://doi. org/10.1590/S0034-89102006000500023.

10. Almeida MSC. Efetividade da escala de depressão geriátrica de cinco itens em população idosa da comunidade [tese]. Porto Alegre (RS): PUCRS; 2010.

11. Vera I, Lucchese R, Nakatani AYK, Pagotto V, Montefusco SRA, Sadoyama G. Funcionalidade familiar em longevos residentes em domicilio. Rev Bras Enferm [Internet]. 2015 [cited 2018 Dec 9];68(1):68-75. https:// doi.org/10.1590/0034-7167.2015680110p.

12. Brandão D, Ribeiro O, Afonso RM, Paúl C. Regional differences in morbidity profiles and health care use in the oldest old: Findings from two Centenarian Studies in Portugal. Arch Gerontol Geriatr. 2019;82(Oct. 2018):13946. https://doi.org/10.1016/j.archger.2019.02.009.

13. Miyawaki CE, Liu M. Gender differences in cognitive impairment among the old and the oldest-old in China. Geriatr Gerontol Int. 2019 Jul;19(7):586-592. https:// doi. org/10.1016/j.archger.2019.02.009.

14. Wang B, He P, Dong B. Association between family functioning and cognitive impairment among Chinese nonagenarians/centenarians. Geriatr Gerontol Int [Internet]. 2015 Sep 1 [cited 2018 Nov 21];15(9):1135-42. Available from: http://doi.wiley.com/10.1111/ggi.12410.
15. Samper-Ternent R, Kuo YF, Ray LA, Ottenbacher KJ, Markides KS, Al Snih S. Prevalence of Health Conditions and Predictors of Mortality in Oldest Old Mexican Americans and Non-Hispanic Whites. J Am Med Dir Assoc [Internet]. 2012 Mar 1 [cited 2018 Mar 27];13(3):254-9. https://doi.org/10.1016/i.jamda.2010.07.010.

16. Tuominen K, Pirhonen J. "Who would take a go-year-old?" Community-dwelling nonagenarians' perceptions of social relationships. Int J Ageing Later Life. 2019;13(1):11137. https://doi.org/10.3384/ijal.1652-8670.18387.

17. Hu X, Gu S, Sun X. Gu Y, Zhen X, Li Y, Huang M, Wei J, Dong $\mathrm{H}$. Cognitive ageing trajectories and mortality of Chinese oldest-old. Arch Gerontol Geriatr. 2019;82:81-87. https://doi.org/10.1016/j.archger.2019.01.018.

18. Holt-Lunstad J, Smith TB, Baker M, Harris T, Stephenson D. Loneliness and Social Isolation as Risk Factors for Mortality: A Meta-Analytic Review. Perspect Psychol Sci [Internet]. 2015 [cited 2019 Jun 26];10(2):227-37. https:// doi.org/10.1177/1745691614568352.

\section{Corresponding author}

Ilva Inês Rigo

Pontificia Universidade Católica do Rio Grande do Sul Av. Ipiranga, 6690, $7^{\circ}$ andar, sala 703

Partenon 90610-000

Porto Alegre, RS, Brasil. 